\title{
Renal cell carcinoma: histological classification and correlation with imaging findings*
}

\author{
Carcinoma de células renais: classificação histológica e correlação com métodos de imagem
}

Valdair F. Muglia ${ }^{1}$, Adilson Prando²

Muglia VF, Prando A. Renal cell carcinoma: histological classification and correlation with imaging findings. Radiol Bras. 2015 Mai/Jun;48(3):166-174.

Abstract Renal cell carcinoma (RCC) is the seventh most common histological type of cancer in the Western world and has shown a sustained increase in its prevalence. The histological classification of RCCs is of utmost importance, considering the significant prognostic and therapeutic implications of its histological subtypes. Imaging methods play an outstanding role in the diagnosis, staging and follow-up of RCC. Clear cell, papillary and chromophobe are the most common histological subtypes of RCC, and their preoperative radiological characterization, either followed or not by confirmatory percutaneous biopsy, may be particularly useful in cases of poor surgical condition, metastatic disease, central mass in a solitary kidney, and in patients eligible for molecular targeted therapy. New strategies recently developed for treating renal cancer, such as cryo and radiofrequency ablation, molecularly targeted therapy and active surveillance also require appropriate preoperative characterization of renal masses. Less common histological types, although sharing nonspecific imaging features, may be suspected on the basis of clinical and epidemiological data. The present study is aimed at reviewing the main clinical and imaging findings of histological RCC subtypes.

Keywords: Renal cell carcinoma; Kidney cancer; Computed tomography; Magnetic resonance imaging.

Resu mo Os carcinomas de células renais (CCRs) são o sétimo tipo histológico de câncer mais comum no mundo ocidental e vêm apresentando uma tendência mantida de aumento em sua prevalência. A classificação histológica dos CCRs é de extrema importância, uma vez que a determinação dos subtipos histológicos tem significativas implicações prognósticas e terapêuticas. Os métodos de imagem têm destacada importância no diagnóstico, estadiamento e seguimento dos pacientes com CCR. As variantes histológicas mais comuns são células claras, papilífero e cromófobo. A caracterização radiológica dos subtipos de CCRs, seguida ou não de biópsia percutânea confirmatória, é particularmente útil em pacientes sem adequadas condições cirúrgicas, pacientes com doença metastática, pacientes com rim único e lesão central, e em pacientes candidatos a terapia de alvo molecular. As novas estratégias, recentemente desenvolvidas, para o tratamento do câncer renal, como crio e radiofrequência, terapia molecular alvo e vigilância ativa também exigem adequada caracterização pré-operatória das massas renais. Os subtipos histológicos menos comuns, apesar de não terem achados de imagem específicos, podem ser suspeitados com base em dados clínicos e epidemiológicos.

Unitermos: Carcinoma de células renais; Câncer renal; Tomografia computadorizada; Ressonância magnética.

\section{INTRODUCTION}

Renal cell carcinomas (RCCs) are the seventh most common histological type of cancer in the Western world and have maintained an increasing prevalence ${ }^{(1,2)}$, representing $1 \%$ to $3 \%$ of all malignant visceral neoplasms. Approximately $40 \%$ of patients with RCC die because of the disease progression, thus this tumor is the most lethal malignant urological tumor. Currently, most RCCs are incidentally found at imaging investigations, whether for urological reasons or

* Study developed at Faculdade de Medicina de Ribeirão Preto da Universidade de São Paulo (FMRP-USP), Ribeirão Preto, SP, Brazil.

1. Postdoctoral Scholar, Associate Professor at Centro de Ciências das Imagens e Física Médica (CCIFM) - Faculdade de Medicina de Ribeirão Preto da Universidade de São Paulo (FMRP-USP), Ribeirão Preto, SP, Brazil.

2. Guest Professor at Universidade Estadual de Campinas (Unicamp), Head of Department of Imaginology at Hospital Vera Cruz, Campinas, SP, Brazil.

Mailing Address: Dr. Valdair Francisco Muglia. Hospital das Clínicas, FMRP-USP Centro de Ciências das Imagens e Física Médica, $2^{\circ}$ andar. Avenida Bandeirantes, 3900, Monte Alegre. Ribeirão Preto, SP, Brazil, 14048-900. E-mail: fmuglia@fmrp. usp.br.

Received September 21, 2013. Accepted after revision April 10, 2014. not. There is a clear predominance of men among patients with RCC, representing two thirds of cases.

The histological classification of RCCs is extremely important, considering the significant implications of the subtypes in the prognosis and treatment of these tumors ${ }^{(3,4)}$. As already known, with the recent developments in immunohistochemistry, imaging-guided percutaneous biopsy became a minimally invasive method with relatively high accuracy $(70-90 \%)$ in the preoperative histopathological characterization of renal tumors ${ }^{(5,6)}$. However, despite its minimum invasiveness, percutaneous biopsy involves risks and limitations and currently it is only indicated in cases where a renal tumor cannot be radiologically characterized or in specific clinical situations.

In this context, a preoperative radiological characterization of RCCs subtypes is of utmost importance and, depending on the clinical situation, it may be supplemented or not by confirmatory percutaneous biopsy. Such a procedure is particularly useful in cases of patients with poor surgical condition, metastatic disease, solitary kidney and tumor lesion 
difficult to be treated by conservative surgery, and in patients eligible for molecular targeted therapy ${ }^{(7-10)}$.

About two decades ago, RCCs were divided between clear cell and granular cell variants ${ }^{(3)}$. Currently, according to the 2004 WHO classification, several histological RCC subtypes are recognized (Table 1). The most frequent histological subtypes include clear cell renal cell carcinomas (ccRCC), papillary renal cell carcinomas (pRCC), and chromophobe renal cell carcinomas (crRCC) (Figure 1). These three subtypes together represent more than $90 \%$ of all $\mathrm{RCCs}^{(11)}$.

Table 1-Main histological subtypes of RCC - epidemiology, histology and imaging characteristics.

\begin{tabular}{|c|c|c|c|c|c|c|c|}
\hline Subtype & $\begin{array}{l}\text { Inci- } \\
\text { dence }\end{array}$ & Origin, histology & Patients' age & Signal/density pattern & Biological behaviour & $\begin{array}{l}\text { Post-contrast } \\
\text { hemodynamic } \\
\text { pattern }\end{array}$ & $\begin{array}{l}\text { Associations } \\
\text { and predispositions }\end{array}$ \\
\hline Clear cell & $75 \%$ & $\begin{array}{l}\text { Proximal nepron, tu- } \\
\text { bular epithelium }\end{array}$ & $>50$ years & $\begin{array}{l}\text { Heterogeneous den- } \\
\text { sity/signal }\end{array}$ & $\begin{array}{l}\text { Aggressive, according to the } \\
\text { stage, Furhman grade and } \\
\text { sarcomatoid transformation }\end{array}$ & Hypervascular & $\begin{array}{l}\text { Von Hippel-Lindau (25- } \\
45 \%) \text {, tuberous sclerosis } \\
(2 \%)\end{array}$ \\
\hline Papillary & $10 \%$ & $\begin{array}{l}\text { Distal nephron, tubu- } \\
\text { lar epithelium }\end{array}$ & $>50$ years & $\begin{array}{l}\text { Low T2 signal, hypo- } \\
\text { dense }\end{array}$ & $\begin{array}{l}\text { Aggressive, according to the } \\
\text { stage, Furhman grade and } \\
\text { sarcomatoid transformation }\end{array}$ & Hypovascular & Hereditary papillary RCC \\
\hline Chromophobe & $5 \%$ & $\begin{array}{l}\text { Distal nephron, in- } \\
\text { tercalated cells of } \\
\text { the distal tubules }\end{array}$ & $>50$ years & $\begin{array}{l}\text { Hypodense, intermedi- } \\
\text { ate signal intensity }\end{array}$ & Low mortality $(10 \%)$ & Hypovascular & $\begin{array}{l}\text { Birt-Hogg-Dubé syn- } \\
\text { drome (in association } \\
\text { with oncocytomas) }\end{array}$ \\
\hline Cystic-solid & $1-4 \%$ & $\begin{array}{l}\text { Similar to renal clear } \\
\text { cell carcinoma, with- } \\
\text { out solid nodules }\end{array}$ & $\begin{array}{l}\text { Fourth and fifth } \\
\text { decades of life }\end{array}$ & $\begin{array}{l}\text { High T2 signal inten- } \\
\text { sity, fluid density }\end{array}$ & Indolent, without metastases & $\begin{array}{l}\text { Septal and solid } \\
\text { portions en- } \\
\text { hancement }\end{array}$ & Predominance in men \\
\hline $\begin{array}{l}\text { Collecting ducts } \\
\text { (Bellini) }\end{array}$ & $1 \%$ & Collecting tubules & $>50$ years & $\begin{array}{l}\text { Low T2 signal, hetero- } \\
\text { geneous }\end{array}$ & $\begin{array}{l}\text { Very aggressive, mortality: } \\
70 \% \text { in two years }\end{array}$ & Hypovascular & $\begin{array}{l}\text { Subtle predominance in } \\
\text { men }\end{array}$ \\
\hline Medullary & $1 \%$ & Distal nephron & $\begin{array}{l}\text { Second and third } \\
\text { decades of life }\end{array}$ & $\begin{array}{l}\text { Heterogeneous, infiltrat- } \\
\text { ing }\end{array}$ & Extremelly aggressive & Hypovascular & $\begin{array}{l}\text { Associated with sickle } \\
\text { cell disease }\end{array}$ \\
\hline $\begin{array}{l}\text { Xp11 transloca- } \\
\text { tion }\end{array}$ & Rare & $\begin{array}{l}\text { Distal/proximal neph- } \\
\text { ron, may be similar to } \\
\text { papillary or clear cell } \\
\text { carcinoma }\end{array}$ & $\begin{array}{l}\text { Children (early } \\
\text { childhood) }\end{array}$ & $\begin{array}{l}\text { Hypodense, intermedi- } \\
\text { ate T2 signal intensity }\end{array}$ & Indolent & Hypovascular & $\begin{array}{l}\text { TFE3 gene involved in } \\
\text { the tumor genesis }\end{array}$ \\
\hline $\begin{array}{l}\text { Mucinous tubu- } \\
\text { lar and spindle } \\
\text { cell }\end{array}$ & Rare & $\begin{array}{l}\text { Distal nephron, tubu- } \\
\text { lar cells }\end{array}$ & $\begin{array}{l}\text { Fourth and fifth } \\
\text { decades of life }\end{array}$ & $\begin{array}{l}\text { Subtle T2 hypersignal, } \\
\text { central scar may be } \\
\text { observed }\end{array}$ & $\begin{array}{l}\text { Slow-growing, rare metasta- } \\
\text { ses }\end{array}$ & Hypovascular & Predominance in women \\
\hline $\begin{array}{l}\text { Associated with } \\
\text { neuroblastoma }\end{array}$ & Rare & $\begin{array}{l}\text { Proximal tubular epi- } \\
\text { thelium }\end{array}$ & $\begin{array}{l}\text { Adolescence } \\
\text { (mean } 13 \text { years) }\end{array}$ & $\begin{array}{l}\text { Hypodense, intermedi- } \\
\text { ate T2 signal intensity }\end{array}$ & Indolent & Hypovascular & $\begin{array}{l}\text { Previous history of neu- } \\
\text { roblastoma }\end{array}$ \\
\hline Non classified & $4-6 \%$ & Variable & Variable & Variable & High mortality & Variable & - \\
\hline
\end{tabular}
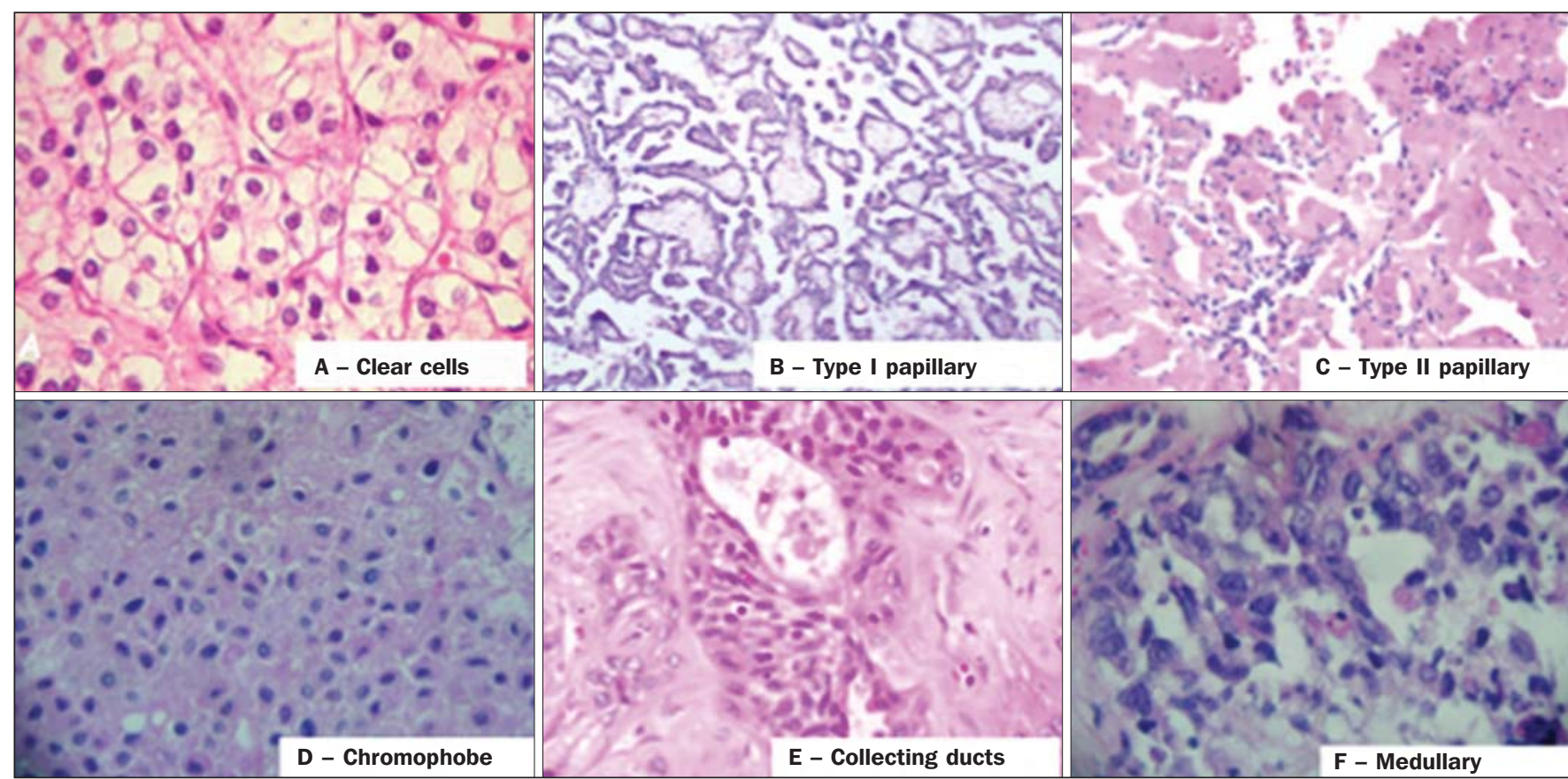

Figure 1. Histology of the most common RCC subtypes. A: Clear cell RCC - cells with lipid-rich ample cytoplasm, hence the name of the neoplasm. B: Type 1 Papillary RCC - small basophilic cells with scarce cytoplasm, organized in a spindle-shaped pattern, in a single layer of cells surrounding the basal membrane. C: Type 2 Papillary RCC - cells organized in a spindle-shaped pattern with papillae covered by cells with abundant eosinophilic granular cytoplasm with prominent nucleoli. D: Chromophobe RCC - large pale cells with reticulated cytoplasm and perinuclear halos. E: Collecting duct RCC - histology shows an irregular, infiltrating cells arrangement in the collecting duct walls, showing remarkable desmoplasia. F: Medullary RCC - it originates in the distal nephron, also with an irregular cell arrangement, remarkable pleomorphism and hyperchromatic nuclei. 
In 2013, the International Society of Urological Pathology (ISUP) proposed a new RCC classification including the $\mathrm{WHO}$ proposal, but suggesting the inclusion of five new, well-characterized types of renal neoplasm and three additional types considered as new and emerging entities ${ }^{(12)}$.

Imaging methods play a relevant role in the diagnosis of RCCs, determining a tendency toward the diagnosis of tumors at earlier stages, besides being essential for staging and therapeutic planning ${ }^{(13)}$.

Recently, some studies have demonstrated that imaging methods can differentiate clear cell renal cell carcinomas from the papillary and chromophobe histological types which are respectively the second and third most common RCC types $^{(14)}$. In addition to the traditional techniques with evaluation of density, signal intensity and pattern of intravenous contrast uptake by the lesion, other techniques, particularly quantitative magnetic resonance imaging (MRI) with diffusion-weighted and perfusion imaging have been employed in the characterization of renal epithelial neoplasms.

The present article is aimed a reviewing the main histological characteristics and imaging findings of the main histological RCC variants, correlating them with clinical cases observed in the authors' institution.

\section{CLEAR CELL CARCINOMA}

This is the most common variant, representing between $70 \%$ and $75 \%$ of all RCCs ${ }^{(3,7)}$. Most clear cell carcinomas (95\%) are sporadic, and the remaining $5 \%$ are associated with hereditary syndromes (von Hippel-Lindau disease, tuberous sclerosis). Clear cell RCC originates from the proximal convoluted tubules epithelium (renal cortex) e presents a predominantly expansile growth pattern. Macroscopically, it is a solid, yellowish lesion with variable degrees of internal necrosis, hemorrhage and cystic degeneration. Such findings are most frequently observed in large-volume, fast-growing tumors. Tumor calcifications may also be found. Histologically, such lesions present clear cells because of their lipid- and glycogen-rich cytoplasmic content ${ }^{(4)}$. Frequently, such tumors also present cell with eosinophil granular cytoplasm. The imaging findings are compatible with such histopathological features, identifying hypervascularized and heterogeneous lesions due to necrosis, hemorrhage, cysts and calcifications. Necrosis is more common in larger lesions, generally with dimensions $>4 \mathrm{~cm}$. The rate of occurrence and degree of necrosis have also been associated with high-grade tumor histology ${ }^{(15,16)}$. At computed tomography (CT), such tumors usually present with intense contrast uptake in the corticomedullary phase (120-140 HU) and typical washout in the nephrographic phase (90-100 HU) (Figure 2).

At MRI, signal intensity similar to the one of the renal cortex at T1-weighted images, and hypersignal at T2-weighted images. Because of the presence of intracellular lipid content, other finding observed in up to $60 \%$ of ccRCC is signal loss at out-of-phase image as the chemical shift imaging technique is employed $^{(17)}$ (Figure 3). It should be observed that this is a nonspecific finding of ccRCC, since it may also be seen in angiomyolipoma without macroscopic fat and, more rarely, also in pRCC. ccRCC may also present a hypodense pseudocapsule in the corticomedullary phase at CT, and with hyposignal at MRI T1- and T2-weighted sequences. Discontinuity of this pseudocapsule generally indicates a high-grade tumor. The comparative analysis of the lesion signal intensity in the corticomedullary phase at contrastenhanced MRI is an effective tool in the differentiation between ccRCC and pRCC. Quantitative analysis of the contrast uptake by tumors at multiphase examinations (corticomedullary, nephrographic and excretory phases) demonstrated that the percentages of signal alteration in the three phases after contrast injection in relation to the pre-contrast phase were significantly higher in ccRCC $(230 \%, 250 \%$ and $227 \%$ for the corticomedullary, nephrographic and excretory phases, respectively) than in pRCC (49\%, 92\% and $88 \%$ for the corticomedullary, nephrographic and excretory phases, respectively), or in crRCC (98\%, 183\% and $159 \%$ corticomedullary, nephrographic and excretory phases, respectively $)^{(14)}$.

Although with still controversial results, until the present moment, the utilization of MRI diffusion-weighted imaging has not been useful in the differentiation of RCC histological subtypes ${ }^{(18)}$.

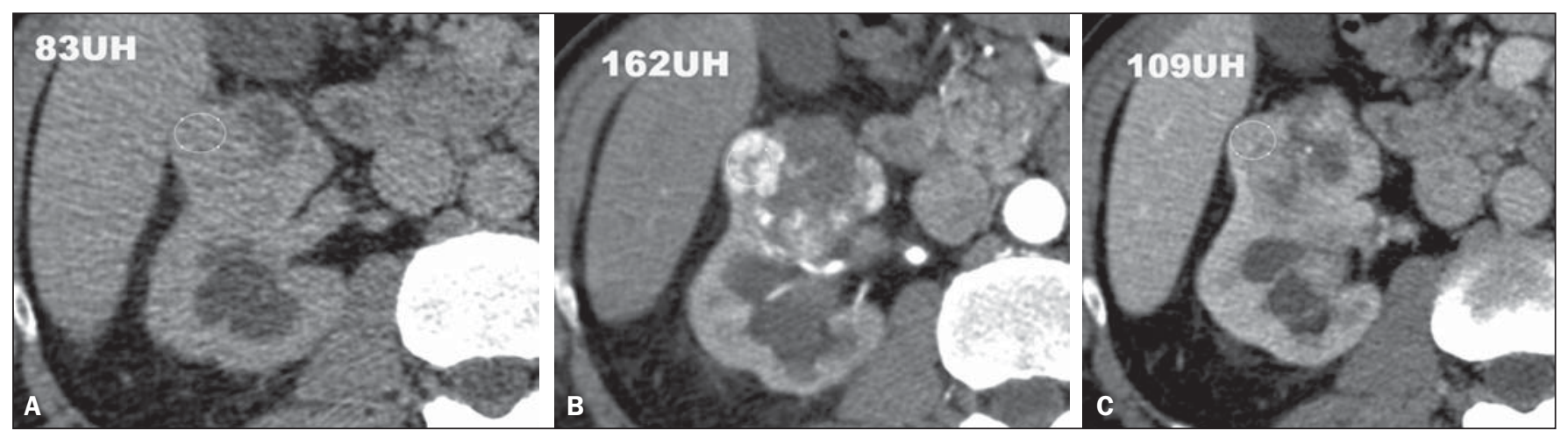

Figure 2. Clear cell RCC variant. CT, pre-contrast (A), corticomedullary (B) and nephrographic (C) phases. Note the expansile heterogeneous lesion with internal cystic components and peripheral solid areas with mean density $=83 \mathrm{HU}$ at the pre-contrast phase, with intense contrast uptake, from $162 \mathrm{HU}$ at the corticomedullary phase to $109 \mathrm{HU}$ at the nephrographic phase. 


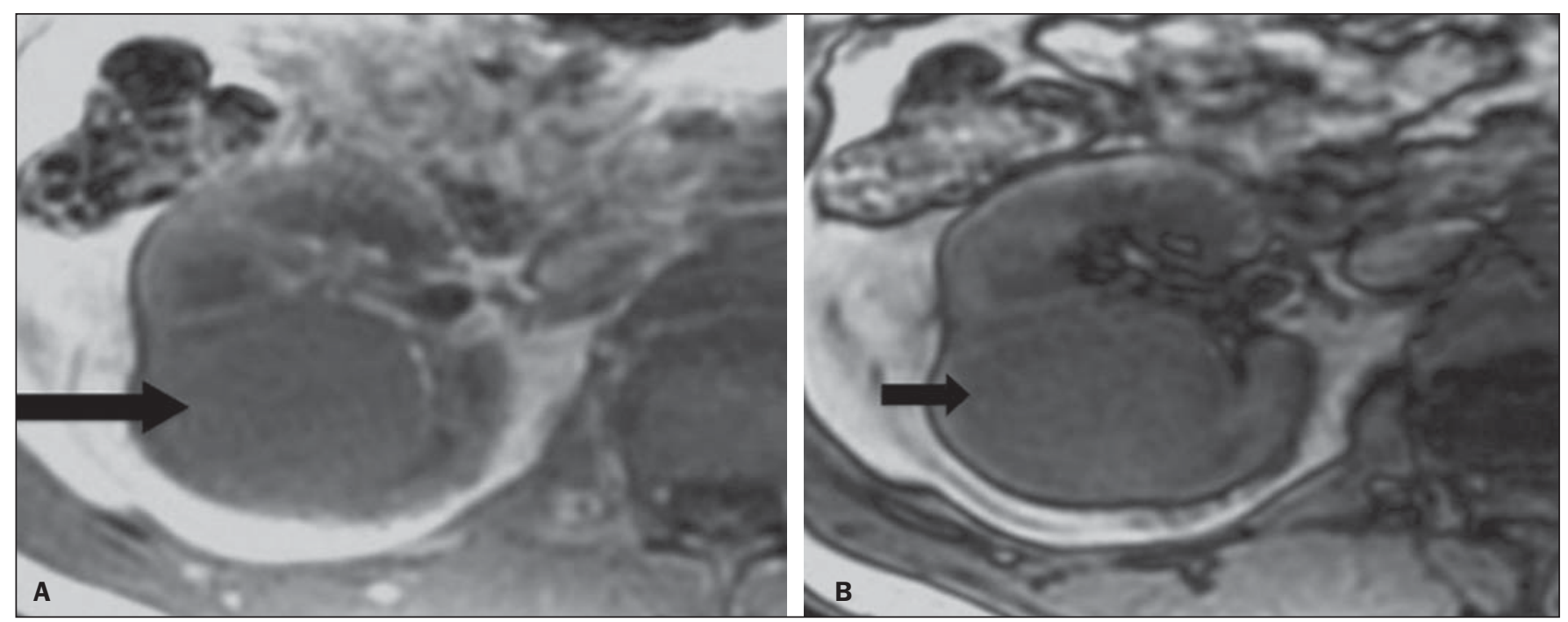

Figure 3. Clear cell RCC variant. MRI with the chemical shift imaging technique. In phase (A) and out of phase (B) images showing expansile, solid lesion in the right kidney (arrows) presenting with subtle signal loss in the out of phase sequence, that is difficult to be visualized, characterized only by the signal intensity loss índex corresponding to $11 \%$ (signal intensity loss index $=$ in phase signal intensity - out of phase signal intensity / in phase signal intensity $\times 100$ ).

Another relatively common finding of these lesions is extension toward the perirenal fat, renal sinus fat and into the renal vein and inferior vena cava. In the presence of venous invasion, perirenal collateral venous circulation is commonly observed.

Hematogenous metastases are relatively common in clear cell carcinomas and affect principally the lungs, liver and bones ${ }^{(19)}$. Lymph node metastases are described in up to $15 \%$ of cases. As a general rule, ccRCC carries a worse prognosis than the other two more common histological subtypes (pRCC and $\mathrm{crRCC})^{(4,11)}$.

\section{PAPILLARY CARCINOMA}

The papillary variant of this tumor is the second most common histological RCC subtype, representing about $10 \%$ of cases in the several series in the literature ${ }^{(3,4)}$. It may also occur sporadically or as a familial condition. On its turn, this variant presents two subtypes based on the histological appearance and biological behavior of the lesion, with quite distinctive prognosis. However, these subtypes cannot be preoperatively differentiated with the current imaging techniques ${ }^{(20)}$.

Histological findings include cells organized in a spindleshaped pattern and possible areas of internal hemorrhage and cystic alterations, particularly in larger lesions ${ }^{(11)}$.

Type 1 (basophilic) pRCC presents a single layer of basophilic cells surrounding the basal membrane. These small cells present scarce clear cytoplasm and hyperchromatic nuclei. On its turn, the histological subtype 2 (eosinophilic) presents with papillae covered by cells with abundant granular eosinophilic cytoplasm, with prominent nucleoli associated with areas of necrosis. Generally, pRCCs carry a better prognosis than ccRCCs. Type 1 pRCC is typically detected at earlier stages and lower grades than type 2 pRCC and therefore are associated with a better prognosis. Usually, at diagnosis, type 2 pRCC appears as a high-grade tumor, frequently associated with ganglial metastasis and, in some cases, with venous invasion. Papillary RCCs tend to be solid, well defined, slow-growing lesions ${ }^{(21)}$. Also, they tend to be bilateral (4\%) and/or multifocal (22.5\%) and are associated with acquired chronic renal disease.

At CT and MRI, such tumors tend to appear more homogeneous than ccRCC and hypovascular as compared with the adjacent renal parenchyma ${ }^{(15,16,22)}$. In the corticomedullary phase at contrast-enhanced $\mathrm{CT}$, these tumors tend to present a mean density ranging between $50-60 \mathrm{HU}$, and 65$75 \mathrm{HU}$ in the nephrographic phase (progressive uptake). At MRI, papillary carcinomas frequently manifest as peripheral lesions with intense hyposignal on T2-weighted images (Figure 4), presumably due to the intratumoral hemosiderin content ${ }^{(23)}$ or to their architectural arrangement. Lesions $>4.0$ $\mathrm{cm}$ in diameter may be heterogeneous due to the presence of necrosis, hemorrhage and calcification. Only rarely these tumors may present internal foci of macroscopic fat (interstitial macrophage with cholesterol) or even intracytoplasmic fat and, in this case, signal loss is also observed on the out of phase sequence at chemical shift imaging.

Papillary RCCs may also present as neoplastic cystic lesions, generally with hemorrhagic content and hypovascular mural solid papillary projections.

\section{CHROMOPHOBE RENAL CELL CARCINOMA}

Chromophobe RCC represents about 5\% of all malignant renal epithelial tumors, and is most frequent in the sixth decade of life. Such a subtype is less aggressive than $\operatorname{ccRCC}^{(3,11)}$, and carries the best prognosis amongst RCCs. Metastasis occurs in only $7 \%$ os cases. Pathologically, such a less aggressive variant is orange colored turning grey after fixation. At microscopy, these tumor present large pale cells with reticulated cytoplasm and perinuclear halos. In the presence of sarcomatoid transformation, the lesion become more 


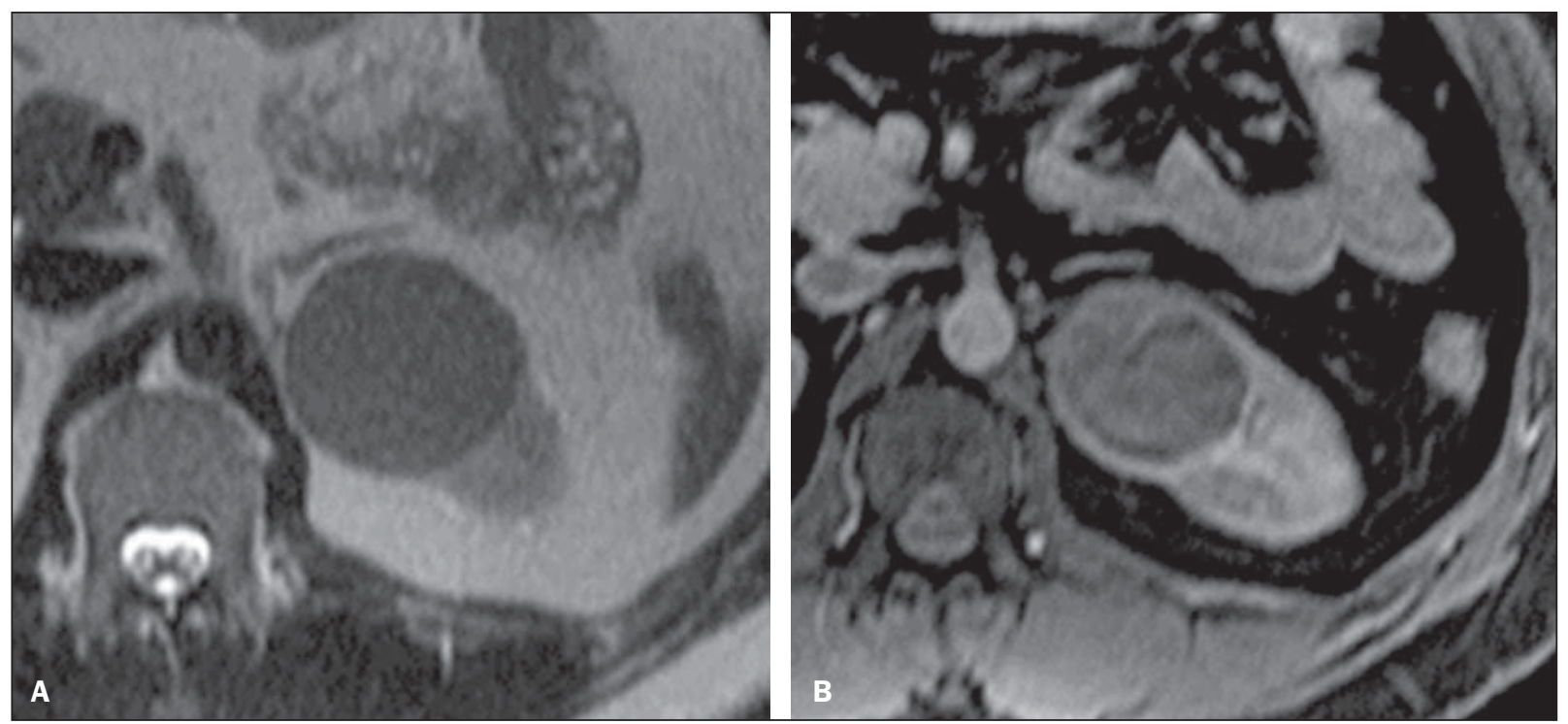

Figure 4. Papillary RCC variant. A: MRI, axial, T2-weighted image showing expansile, homogeneous lesion with intense hyposignal. B: Contrast-enhanced MRI, axial, T1-weighted image showing a remarkably hypovascular lesion in relation to the adjacent cortex.

aggressive, with a considerably worse prognosis ${ }^{(3,24)}$. Some pathologists believe that there is a very close relationship between the chromophobe variant and oncocytomas. Both would be originated from collecting ducts intercalated cells and constitute common associated findings in cases of BirtHogg-Dubé syndrome ${ }^{(25)}$.

At imaging studies, chromophobe carcinomas tend to be more homogeneous than clear cell carcinomas ${ }^{(13,14,21)}$. Such lesions are hypovascular as compared with the renal cortex, and most of times present a moderate contrast uptake (80-100 HU in the corticomedullary phase at CT scan), and therefore less intense than the clear cell variant, and more intense as compared with the papillary variant ${ }^{(21)}$ (Figure 5). Not rarely, however, crRCC may appear as a homogeneous and remarkably vascularized lesion in the corticomedullary phase (120-140 HU). At MRI, the lesion tends to present a slight hyposignal or intermediate signal intensity at T2-weighted sequences (Figure 6), and also may present a central scar. It is important to note that findings of crRCC are indistinguishable from those of oncocytomas (benign tumors originated from intercalated type B cells of the cortical collecting ducts), which may also present a central scar. Necrosis may occur in the voluminous lesions.

\section{COLLECTING DUCT CARCINOMA (BELLINI DUCT CARCINOMA)}

This rare RCC variant represents less than $1 \%$ of all malignant kidney tumors, but it is important to highlight the high aggressiveness of this lesion ${ }^{(3,9,26)}$, whose prognosis is quite unfavorable since $30 \%$ of patients already present with metastasis at the diagnosis, and $60-70 \%$ of them die within a two-year period $^{(27)}$.
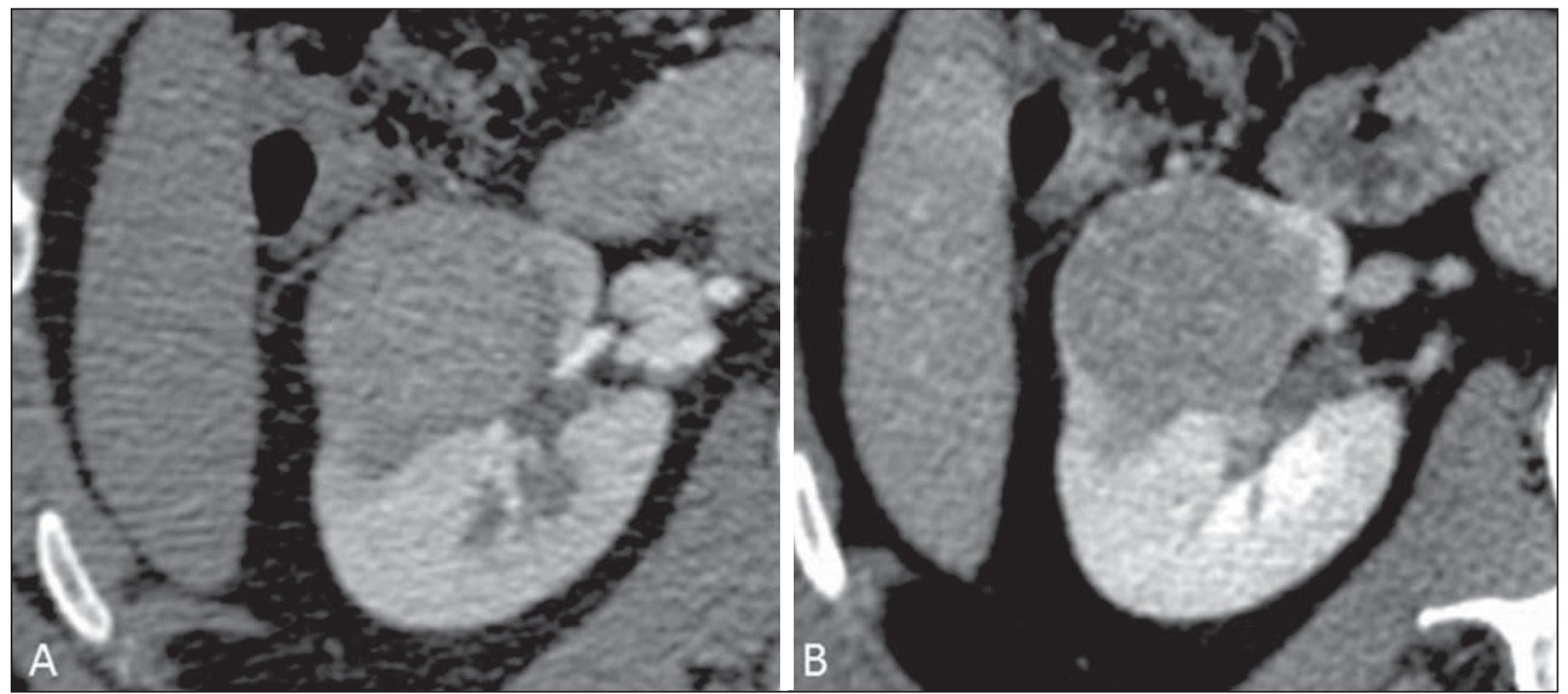

Figure 5. Chromophobe RCC. CT, corticomedullary (A) and nephrographic (B) phases showing expansile, solid lesion with homogeneous contrast uptake, with mean density $=92 \mathrm{HU}$ and $126 \mathrm{HU}$, respectively. 


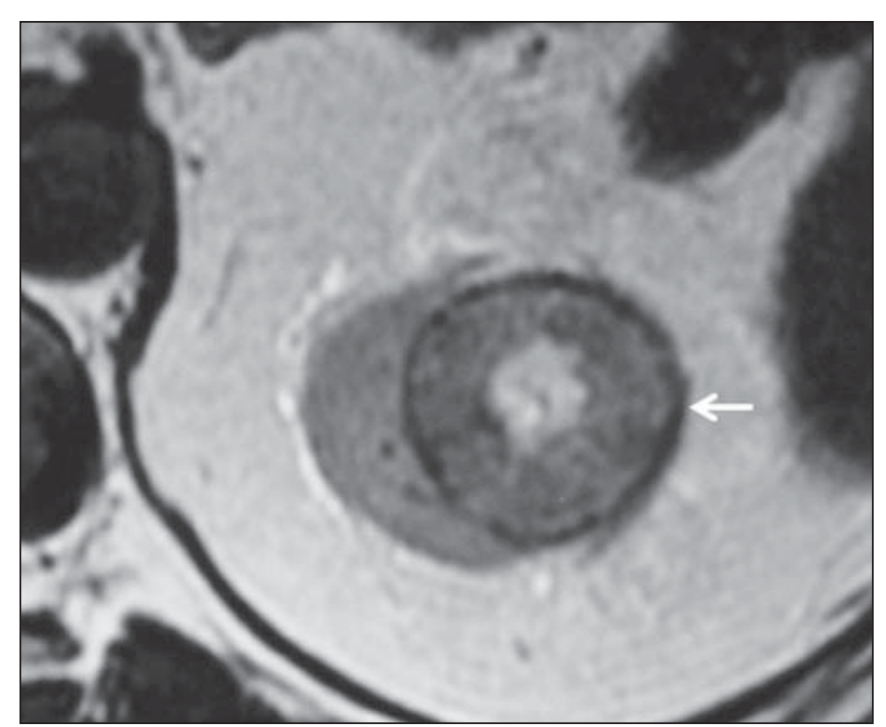

Figure 6. Chromophobe RCC. MRI, axial T2-weighted image identifying expansile, well delimited lesion in left kidney, with intermediate signal intensity, a distinct pseudocapsule (arrow) and a central scar area.

Histologically, collecting duct renal cell carcinoma (cdRCC) is characterized by an irregular, infiltrating cells arrangement in the collecting duct walls, showing remarkable desmoplasia ${ }^{(13)}$. A subtle male prevalence is observed, and in general such lesions show up after the fifth decade of life. At imaging studies, cdRCCs appear as heterogeneous lesions with extremely variable signal intensity on T2weighted sequences, depending on the amount of hemorrhage, necrosis, cystic component and calcification; and frequently present hyposignal at those sequences (Figure 7). In general, and typically, the lesions originate in the medulla, implying a differential diagnosis with transitional cell carcinoma $^{(28)}$. Larger lesions may invade the cortex. Most of these lesions are solid, but some of them may present as complex lesions ${ }^{(26)}$. They are hypovascular at multidetector CT as well as at MRI, tending to heterogeneous or peripheral contrast uptake.

\section{MULTILOCULAR CYSTIC RENAL CELL CARCINOMA}

It is a very infrequent lesion, with incidence ranging between $1-4 \%$ of all RCCs ${ }^{(29)}$, with prevalence in men (male/ female ratio $3: 1)$ at mean age of 50 years. This tumor appears as a multiseptated cystic lesion separated from the kidney by a fibrous capsule ${ }^{(16)}$. It carries an excellent prognosis and can be completely cured. Recurrence and metastasis have not been described.

Histopathological analysis reveals serous, gelatinous or hemorrhagic cysts lined by a single layer of small collections of epithelial cells with clear cytoplasm. Development of solid nodules is not observed. This finding differentiates multilocular cystic RCC from ccRCC with extensive cystic degeneration $^{(30)}$.

Calcification in septa or in the pseudocapsule occurs in up to $20 \%$ of cases. At CT and MRI, these tumors appear as complex cysts, classified as II-F to IV categories according to the Bosniak system ${ }^{(16)}$ (Figure 8).

\section{MEDULLARY RENAL CELL CARCINOMA}

This rare variant of RCC was first described in 1995 by Davis. Some pathologists consider this variant as a cdRCC subtype $^{(31)}$. Besides being rare, it is an extremely aggressive tumor, originating in the distal nephrons, from the collecting duct cells. A remarkable feature of this histological tumor subtype is its association with sickle cell disease and sickle cell trait. Typically, as a result from such association, medullary renal cell carcinomas affect young patients at the second and third decades of their lives.
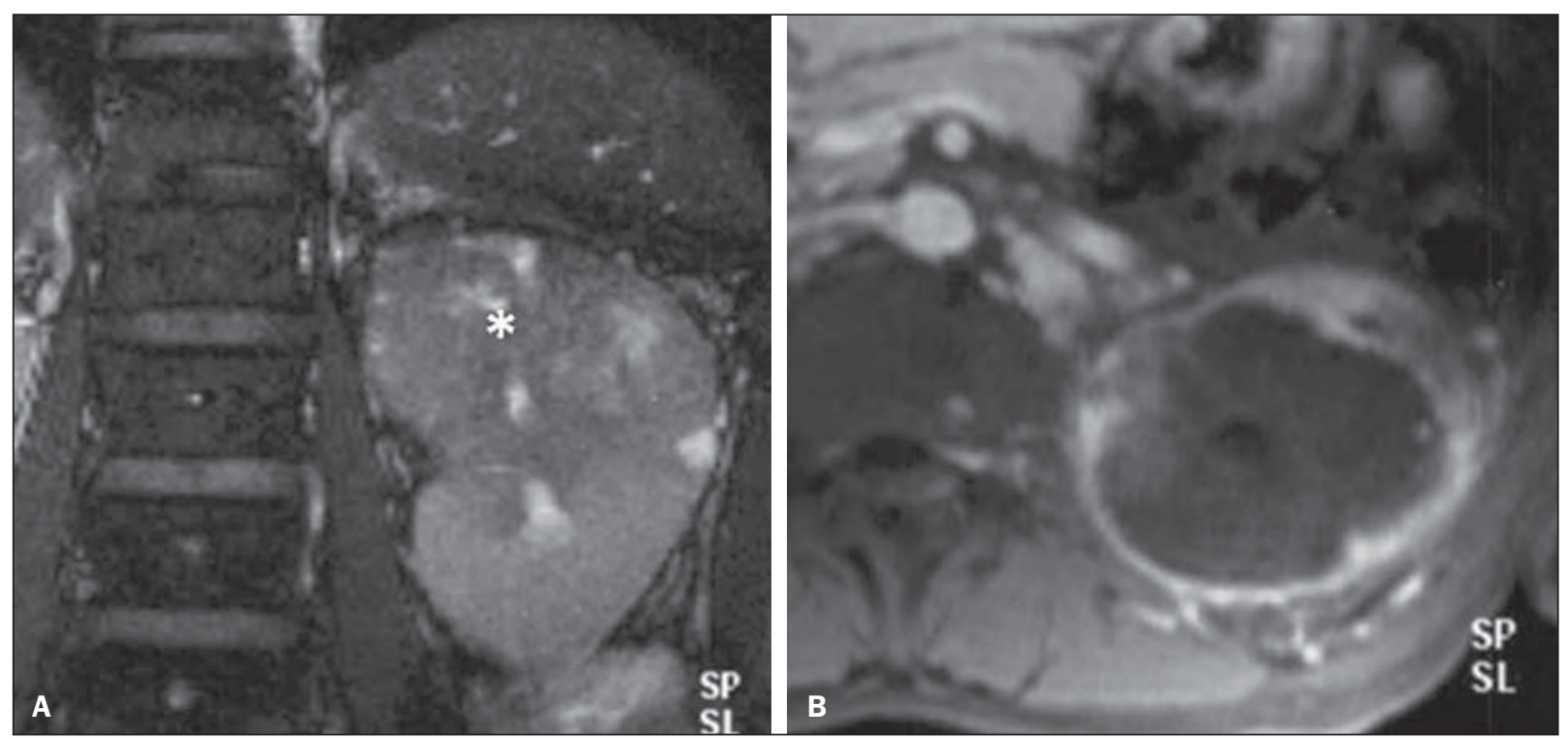

Figure 7. Collecting duct RCC. A: MRI, coronal plane, T2-weighted image showing expansile, irregular lesion in the upper pole of left kidney, with heterogeneous signal intensity and predominance of hyposignal (asterisk). B: Contrast-enhanced MRI, axial, T1-weighted image. The lesion presents predominantly peripheral, heterogeneous signal intensity, considerably less intense than the renal cortex. 


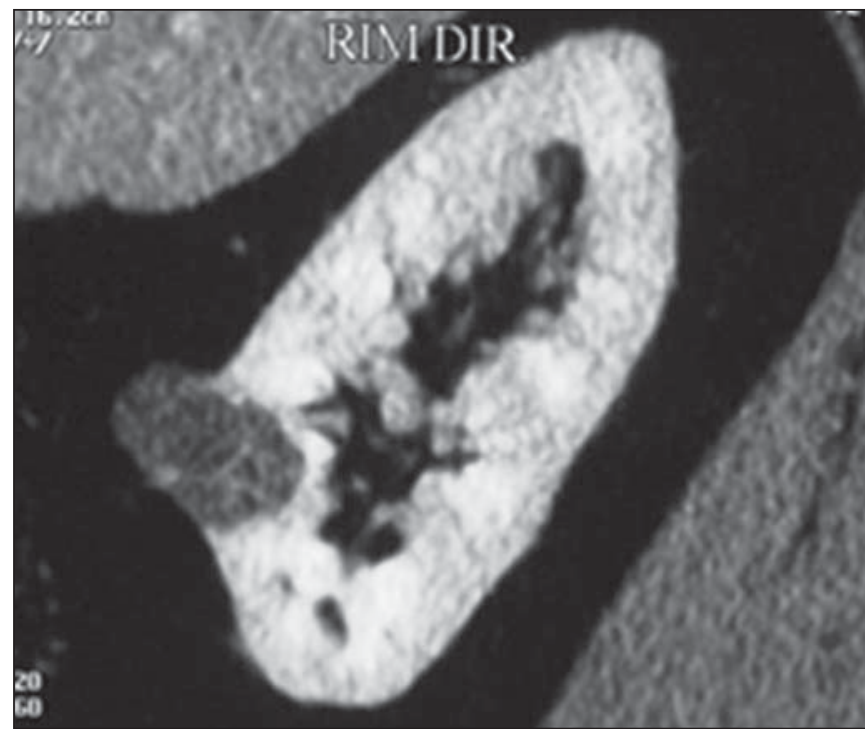

Figure 8. Multilocular cystic RCC. A: Sagittal reconstruction of CT nephrographic phase image showing the multilocular cystic nature of the lesion.

At imaging studies, this tumor appears as infiltrating lesions causing calyceal obstruction and dilatation. It is a hypovascular lesion (Figure 9) and is frequently associated with locoregional adenopathy ${ }^{(32)}$.

\section{RENAL MUCINOUS TUBULAR AND SPINDLE CELL CARCINOMA (MTSCC)}

This recently described, very rare renal tumor originates from distal convoluted tubule cells and collecting ducts. A clear female prevalence is observed, generally with occurrence in the fourth and fifth decades of life ${ }^{(3,11)}$. It is considered to be a low-grade neoplasm, and among the few cases described in the literature up till this moment, none presented proliferation. At histology, this tumor is composed of densely clustered cells intermingled with clear mucinous stroma and a well defined spindle cell component ${ }^{(4)}$.

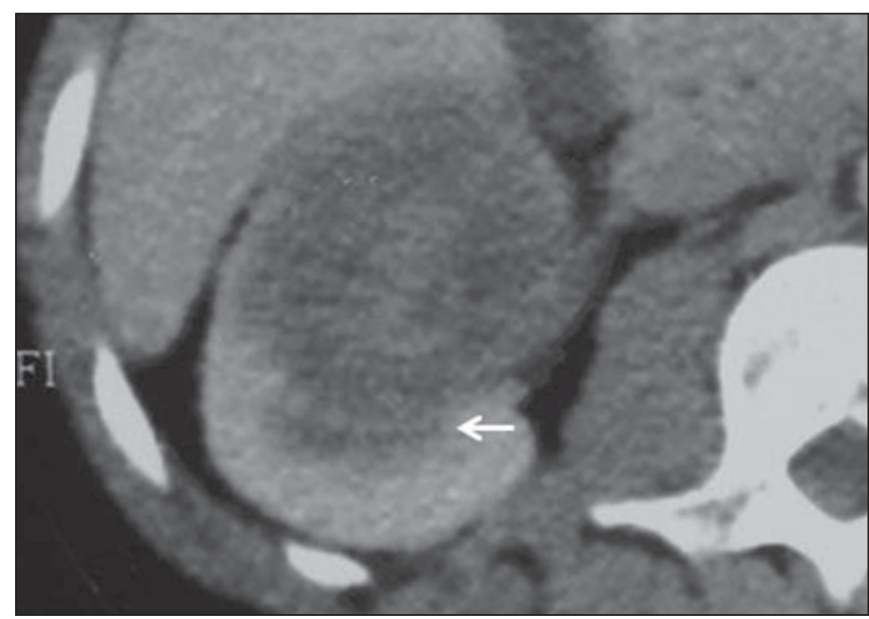

Figure 9. Medullary RCC. Male, 25-year-old patient with sickle-cell disease. Contrast-enhanced $\mathrm{CT}$ image showing extensive, solid, hypovascular, predominantly medullary and slightly heterogeneous lesion in the right kidney. Observe the infiltrating feature of the lesion in the pyelocalyceal system (arrow) and in the proximal portion of the ureter.
At imaging studies, MTSCCs do not present any typical feature, and in the few cases reported until de present moment they appear as circumscribed nodules or masses incidentally found at ultrasonography and CT. Typically, these tumors tend to be homogeneous, with low signal intensity at $\mathrm{T} 1$-weighted sequences and intermediate to slightly hyperintense signal at T2-weighted sequences ${ }^{(22)}$. Some of these lesions may present with an irregular central scar. After intravenous contrast agent injection, it is hypovascular in relation to the adjacent cortex, and in cases where a central scar is present (Figure 10) the tumor may present variable opacification degrees ${ }^{(33)}$.

\section{RENAL CELL CARCINOMA ASSOCIATED WITH CHROMOSOME'S SHORT ARM TRANSLOCATION}

This is a recently described and quite rare type of neoplasm, whose origin involves the TFE3 gene and 11 Xp1 1.2 chromosome's short arm translocation ${ }^{(3,4)}$. In general, this neoplasm is found in children and young adults. As regards pathological findings, macroscopically it resembles a ccRCC and appears as a well delimited mass with pseudocapsule. Histologically, however, it presents papillary projections resembling a pRCC. It carries a more indolent prognosis as compared with the clear cell variant ${ }^{(34)}$. There is no characteristic finding for these lesions which in general may appear as heterogeneous lesions, particularly the larger and hypervascular ones ${ }^{(35)}$.

\section{RENAL CELL CARCINOMA ASSOCIATED WITH NEUROBLASTOMA}

This is also an exceptionally rare. There are only few cases described in the literature about children who developed RCC after being treated for neuroblastoma ${ }^{(3,36)}$. It may be either uni- or bilateral and there is no predilection for gender. Considering that it occurs after treatment for neuroblastoma, generally it affects young patients at a mean age of 13 years. In the rare cases described, this type of neoplasm appears as a well delimited, hypovascular lesion, generally with a more indolent behavior ${ }^{(34)}$.

\section{UNCLASSIFIED RENAL CARCINOMAS}

Even with the classification developed in $2004,4 \%$ to $6 \%$ of the neoplasms cannot yet be histologically characterized with accuracy ${ }^{(3,5)}$, which could be improved with the Vancouver classification proposed by ISUP ${ }^{(12)}$. Tumors in this category are histologically heterogeneous and, in most cases, rated as high-grade lesions. Some findings are useful to identify such lesions, as follows: presence of sarcomatoid component without any recognized epithelial elements; production of mucin; presence of mixed stromal and epithelial elements; and non-recognized cell types ${ }^{(37)}$. This category includes the histological RCC subtypes with worst prognosis. 

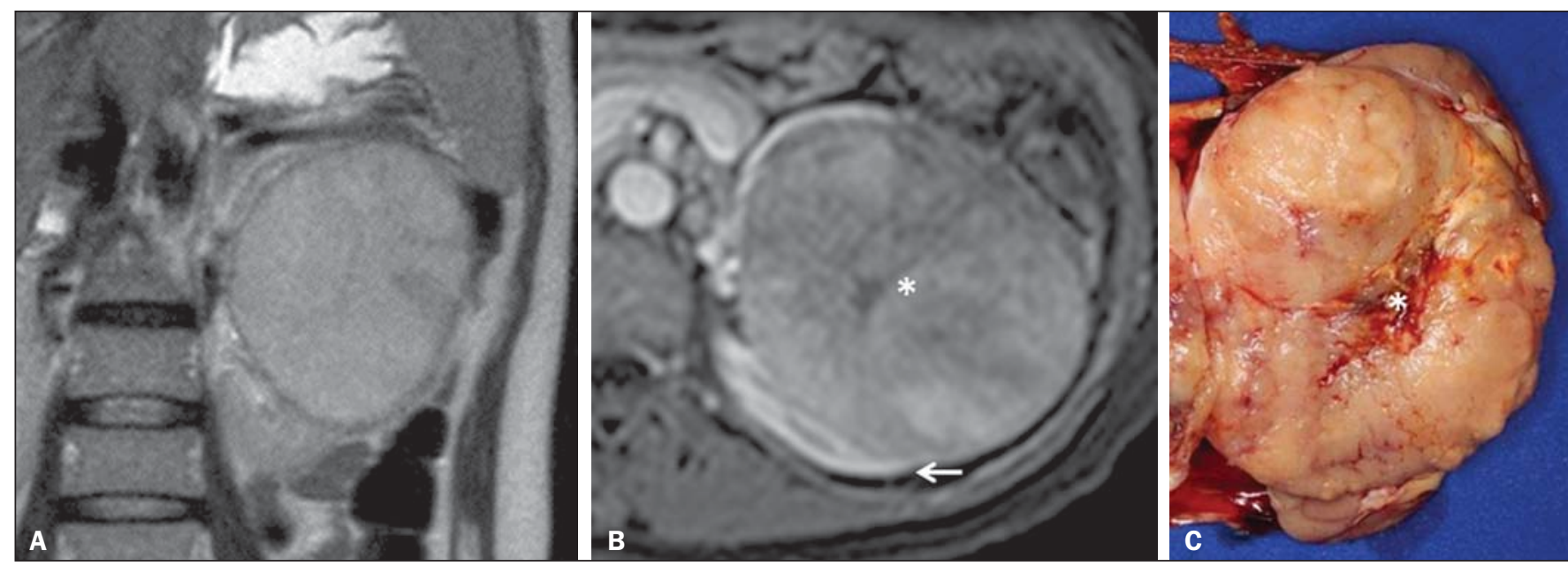

Figure 10. Renal mucinous tubular and spindle cell carcinoma. Female, 57-year-old patient with hematuria. A: MRI, T2-weighted image showing expansile lesion with intermediate signal intensity, and (B) contrast-enhanced nephrographic phase showing hypovascular lesion - compare with the cortex (arrow). Observe the hyposignal of the scar (asterisk). Despite the large dimensions of the lesion, it is well delimited, with no infiltrating feature. C: Surgical specimen showing a circumscribed, yellowish lesion with central scar (asterisk).

\section{CONCLUSION}

The histological classification of RCCs is of utmost importance, considering the significant prognostic and therapeutic implications of its histological subtype, and hence the relevance of the role played by the radiologist in the preoperative imaging recognition of the histological RCC subtypes. Currently, better results have been achieved in the differentiation between clear cell renal cell carcinomas and non clear cell RCCs in the daily clinical practice. It is expected that results of further prospective studies add new information to the current body of data about this matter.

\section{REFERENCES}

1. Jemal A, Siegel R, Ward E, et al. Cancer statistics, 2008. CA Cancer J Clin. 2008;58:71-96.

2. Ljunberg B, Campbell SC, Cho HY, et al. The epidemiology of renal cell carcinoma. Eur Urol. 2011;60:615-21.

3. Lopez-Beltran A, Scarpelli M, Montironi R, et al. 2004 WHO classification of renal tumours of the adults. Eur Urol. 2006;49:798805.

4. Decastro GJ, McKiernan JM. Epidemiology, clinical staging, and presentation of renal cell carcinoma. Urol Clin North Am. 2008; 35:581-92.

5. Dechet CB, Zincke H, Sebo TJ, et al. Prospective analysis of computerized tomography and needle biopsy with permanent sectioning to determine the nature of solid renal masses in adults. J Urol. 2003;169:71-4.

6. Silverman SG, Gan YU, Mortele KJ, et al. Renal masses in the adult patient: the role of percutaneous biopsy. Radiology. 2006;240:6-22.

7. Upton MP, Parker RA, Youmans A, et al. Histologic predictors of renal cell carcinoma response to interleukin-2-based therapy. J Immunother. 2005;28:488-95.

8. Motzer RJ, Hutson TE, Tomczak P, et al. Sunitinib versus interferon alfa in metastatic renal-cell carcinoma. N Engl J Med. 2007; 356:115-24.

9. Escudier B, Eisen T, Stadler WM, et al. Sorafenib in advanced clearcell renal-cell carcinoma. N Engl J Med. 2007;356:125-34.

10. Dutcher JP, Szczylik C, Tannir N, et al. Correlation of survival with tumor histology, age, and prognostic risk group for previously untreated patients with advanced renal cell carcinoma (adv RCC) re- ceiving temsirolimus (TEMSR) or interferon-alpha (IFN) [Abstract] J Clin Oncol. 2007;25(Suppl 18):5033.

11. Lopez-Beltran A, Carrasco JC, Cheng L, et al. 2009 update on the classification of renal epithelial tumors in adults. Int J Urol. 2009, $16: 432-43$.

12. Delahunt B, Srigley JR, Montironi R, et al. Advances in renal neoplasia: recommendations from the 2012 International Society of Urological Pathology Consensus Conference. Urology. 2014;83: 969-74.

13. Catalano C, Fraioli F, Laghi A, et al. High-resolution multidetector $\mathrm{CT}$ in the preoperative evaluation of patients with renal cell carcinoma. AJR Am J Roentgenol. 2003;180:1271-7.

14. Vargas HA, Chaim J, Lefkowitz RA, et al. Renal cortical tumors: use of multiphasic contrast-enhanced MR imaging to differentiate benign and malignant histologic subtypes. Radiology. 2012;264: 779-88.

15. Pedrosa I, Sun MR, Spencer M, et al. MR imaging of renal masses: correlation with findings at surgery and pathologic analysis. Radiographics. 2008;28:985-1003.

16. Prasad SR, Humphrey PA, Catena JR, et al. Common and uncommon histologic subtypes of renal cell carcinoma: imaging spectrum with pathologic correlation. Radiographics. 2006;26:1795-806.

17. Prando A. Intratumotal fat in a renal cell carcinoma. AJR Am J Roentgenol. 1991;156:871.

18. Sandrasegaran K, Sundaram CP, Ramaswamy R, et al. Usefulness of diffusion-weighted imaging in the evaluation of renal masses. AJR Am J Roentgenol. 2010;194:438-45.

19. Feltrin LT, Ferreira JR, Mamere AE, et al. Signs of hypervascularization at magnetic resonance imaging in bone metastases from renal cell carcinoma. Radiol Bras. 2009;42:155-7.

20. Yoshimitsu K, Kakihara D, Irie H, et al. Papillary renal carcinoma: diagnostic approach by chemical shift gradient-echo and echo-planar MR imaging. J Magn Reson Imaging. 2006;23:339-44.

21. Lubensky IA, Schmidt L, Zhuang Z, et al. Hereditary and sporadic papillary renal carcinomas with c-met mutations share a distinct morphological phenotype. Am J Pathol. 1999;155:517-26.

22. Egbert ND, Caoili EM, Cohan RH, et al. Differentiation of papillary renal cell carcinoma subtypes on CT and MRI. AJR Am J Roentgenol. 2013;201:347-55.

23. Karlo CA, Donati OF, Burger IA, et al. MR imaging of renal cortical tumours: qualitative and quantitative chemical shift imaging parameters. Eur Radiol. 2013;23:1738-44. 
24. Liu L, Qian J, Singh H, et al. Immunohistochemical analysis of chromophobe renal cell carcinoma, renal oncocytoma, and clear cell carcinoma: an optimal and practical panel for differential diagnosis. Arch Pathol Lab Med. 2007;131:1290-7.

25. Prando A, Prando D, Prando P. Renal cell carcinoma: unusual presentations. Radiographics. 2006;26:233-44.

26. Srigley JR, Eble JN. Collecting duct carcinoma of kidney. Semin Diagn Pathol. 1998;15:54-67.

27. Outwater EK, Bhatia M, Siegelman ES, et al. Lipid in renal clear cell carcinoma: detection on opposed-phase gradient-echo MR images. Radiology. 1997;205:103-7.

28. Orsola A, Trias I, Raventós CX, et aI. Renal collecting (Bellini) duct carcinoma displays similar characteristics to upper tract urothelial cell carcinoma. Urology. 2005;65:49-54.

29. Murad T, Komaiko W, Oyasu R, et al. Multilocular cystic renal cell carcinoma. Am J Clin Pathol. 1991;95:633-7.

30. Eble JN, Bonsib SM. Extensively cystic renal neoplasms: cystic nephroma, cystic partially differentiated nephroblastoma, multilocular cystic renal cell carcinoma, and cystic hamartoma of renal pelvis. Semin Diagn Pathol. 1998;15:2-20.
31. Liu Q, Galli S, Srinivasan R, et al. Renal medullary carcinoma: molecular, immunohistochemistry, and morphologic correlation. Am J Surg Pathol. 2013;37:368-74.

32. Khan A, Thomas N, Costello B, et al. Renal medullary carcinoma: sonographic, computed tomography, magnetic resonance and angiographic findings. Eur J Radiol. 2000;35:1-7.

33. Lima MS, Barros-Silva GE, Pereira RA, et al. The imaging and pathological features of a mucinous tubular and spindle cell carcinoma of the kidney: a case report. World J Surg Oncol. 2013;1 1:34.

34. Srigley JR, Delahunt B. Uncommon and recently described renal carcinomas. Mod Pathol. 2009;22 Suppl 2:S2-S23.

35. Koo HJ, Choi HJ, Kim MH, et al. Radiologic-pathologic correlation of renal cell carcinoma associated with Xp 11.2 translocation. Acta Radiol. 2013;54:827-34.

36. Fleitz JM, Wootton-Gorges SL, Wyatt-Ashmead J, et al. Renal cell carcinoma in long-term survivors of advanced stage neuroblastoma in early childhood. Pediatr Radiol. 2003;33:540-5.

37. Cheville JC, Lohse CM, Zincke H, et al. Comparisons of outcome and prognostic features among histologic subtypes of renal cell carcinoma. Am J Surg Pathol. 2003;27:612-24. 